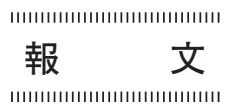

\title{
タラノキの生育に及ぼすエテフォンとジベレリン処理の影響
}

\author{
杉浦 広 幸* \\ 福島学院大学短期大学部
}

(2004 年 10 月 8 日受付, 2005 年 1 月 5 日受理)

\section{Effects of Ethephon and Gibberellin Applications on Growth of Taranoki (Aralia elata Seem.)}

\author{
Hiroyuki SUGIURA* \\ Fukushima College, Miyashirochigoike, Fukushiima, 960-0181, Japan
}

\begin{abstract}
The effects of ethephon applications on growth were studied in cultivation of shoots in Taranoki (Aralia elata Seem.). The growths of stem and internode after spraying with 50-200 mg/l ethephon were shorter than those without ethephon application. Internode growths after spraying with 50-200 mg/l ethephon were shorter than those without application. Stem diameters increased after spraying with $50-200 \mathrm{mg} / 1$ ethephon spray. Stem growths and sucker formations were promoted by spraying with $50 \mathrm{mg} / 1$ gibberellin. Lateral bud growth was promoted by spraying with $200 \mathrm{mg} / \mathrm{l}$ of gibberellin. The results, show that stem diameters increased after spraying of ethephon, and stem growth and vegetative growth were promoted by spraying of gibberellin in Taranoki. (C) Pesticide Science Society of Japan
\end{abstract}

Keywords: Aralia elata Seem., ethephon, gibberellin, growth, diameter of stem, internode.

\section{緒言}

タラノキ (Aralia elata Seem.) は, 山菜として野生の株が 利用されるだけでなく，近年では栽培化が進んでいる ${ }^{1)}$. 商 品価值の高い大きな芽を収穫するため, 苗の生育促進と茎 の肥大が望まれる。露地栽培の植物の生育と形態を調節す る方法として，成長調節剂の利用がある2). 著者らはエテ フォンの散布処理で, キクの栄養成長期間を延長し，伸長 成長を促進するとともに, 茎を肥大化させる作用があるこ とを報告した ${ }^{3)}$. また，植物の伸長を促す成長調節物質シ ベレリン4,5) をキクに処理すると，キクの伸長成長を促進し た6,7). さらに宿根草のキクの栽培現場では, エテフォンの 散布により, 冬至芽の採取数を増加させた（平成 3 年新潟 県花卉栽培指針)。そこで，これらの知見をもとにタラノキ

* To whom correspondence should be addressed.

E-mail: hirosugiu2@tree.odn.ne.jp

(c) Pesticide Science Society of Japan
の成長調節物質としてエテフォンとジベレリンを活用する ことにより，伸長成長や栄養成長の促進効果が期待できる と考え実験を行った。

\section{実 験 方 法}

本実験において用いたタラノキは, 妙高林間園芸研究所 実験地（新潟県妙高高原町：海抜 $640 \mathrm{~m}$, 無施肥, pH 5.0, コナラ林）における維持株を用い，すべての栽培実験は 2004 年 5 月〜9 月に行った.

1. 伸長成長, 茎径, 葉数, 葉径および腋芽誘導に及ぼ すエテフォンの影響

供試材料として, 1 年 2 年生株を用いた. 実験区は対照 無散布区，エテフォン $50 \mathrm{mg} / 1$ 処理区， $200 \mathrm{mg} / 1$ 処理区， $500 \mathrm{mg} / \mathrm{l}$ 処理区および $1,000 \mathrm{mg} / 1$ 処理区をそれぞれ設けた. エテフォンは $10 \%$ 液剤（石原産業 K. K., ‘エスレル $10 ’$ ） を希釈し，株全体へ展着剤なしでハンドスプレーにより 5 
月 6 日，5月 21 日扰よび 6 月 4 日の 3 回散布処理した。調 查は伸長成長（春に伸長開始部から茎の頂部の長さ）, 茎径 (伸長開始部加 $5 \mathrm{~cm}$ 上部), 葉数, 葉径 (処理後に展開し た葉の中で最も大きい葉の最大横幅）および腋芽の長さ （最も伸長した腋芽の長さ）について，8 月 30 日に各区 20 株を用いて実施した。

\section{2. 伸長成長，茥径，葉数，葉径および腋芽誘導に及ぼ} すジベレリンの影響

供試材料として，1 年 2 年生株を用いた。実験区は対照 無散布区，ジベレリン $10 \mathrm{mg} / 1$ 散布区，ジベレリン $50 \mathrm{mg} / 1$ 散布区，ジベレリン $200 \mathrm{mg} / 1$ 散布区およびジベレリン 500 $\mathrm{mg} / \mathrm{l}$ 散布区を設けた。ジベレリンは $3.1 \%$ 製剂（協和醴醅 工業 K.K., “ジベレリン協和粉末”）を所定量の水で溶解し， 1 と同様の方法で，5月 15 日，5月 30 日扔よび 6 月 14 日 の 3 回散布処理した。調查は 1 と同様の項目について 8 月 30 日に実施した。

\section{3. 吸枝の生育に及ぼすエテフォンおよびジベレリンの影}

実験围場の $4 \mathrm{~m}^{2}$ の範囲に, タラノキの 3 年生以上の株か $3 \sim 5$ 本生育している区域 $4 \mathrm{~m}^{2}$ を 1 区域として用いた。実験 区は対照無散布区，エテフォン 3 回散布区およびジベレリ ン 3 回散布区を設けた。エテフォン処理濃度は $200 \mathrm{mg} / \mathrm{l}$, ジ ベレリン処理濃度は $50 \mathrm{mg} / 1$ とし，5月 26 日，6月 25 日お よび 7 月 25 日に処理した。そのほかの方法は，1 抢よび 2 と同様とした。調査は, 各区域内に生育した吸枝の発生数 を 9 月 25 日に各区 3 区域ずつ実施し，吸枝の草丈の計測に は各処理区 18 株をそれぞれ用いた。

\section{結果}

1. 伸長成長, 茎径, 葉数, 葉径および腋芽誘導に及ぼ すエテフォンの影響

タラノキの伸長成長は，エテフォン濃度が高くなるほど 抑制される傾向にあった（Fig. 1A）。 また，エテフォン 500 $\mathrm{mg} / \mathrm{l}$ 処理区と $1000 \mathrm{mg} / \mathrm{l}$ 処理区では, 処理後に伸長成長が 停止した．茎径は，エテフォン 50 200 mg/散布区において 増加し, 茎の肥大化が観察された（Fig. 1B）。エテフォン $50 \sim 200 \mathrm{mg} / 1$ 処理区の葉数之対照無散布区の葉数は，ほほ 同じであったが，前者の節間長は後者のそれより縮小され た（Table 1)。また，エテフォン 500 1000 mg/l 処理区の葉 数は，生育が停止したため対照無散布区に比べ少なかった. 葉径については，50 200 mg/l エテフォン処理区と対照無散 布との間に有意な差がなく，また $1000 \mathrm{mg} / 1$ 処理区では散布 処理にともなう落葉のため測定できなかった．腋芽は，す べての区で誘導されなかった。
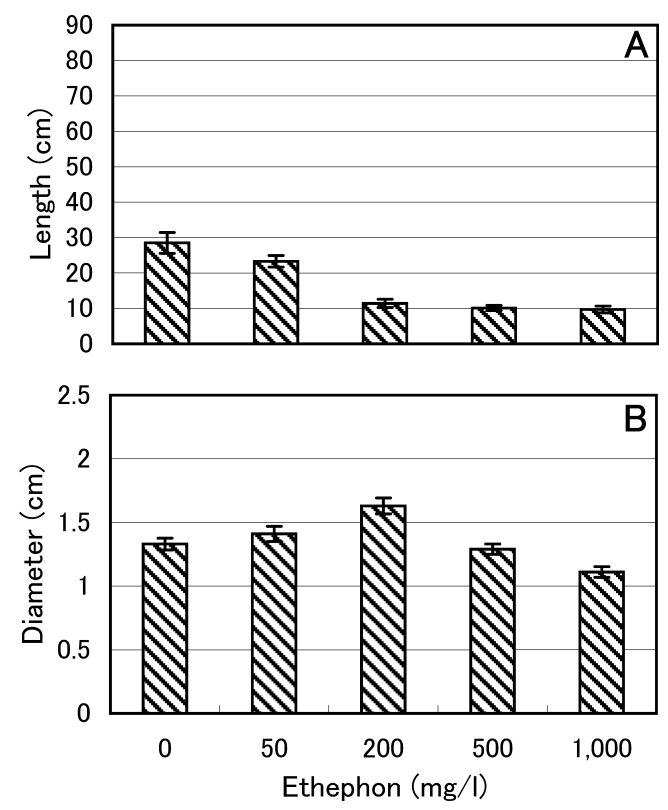

Fig. 1. Effects of ethephon spray on all plants in the $1 \mathrm{~m}^{2}$ field on shoot elongation and diameters of stem leaf in A. elata. A: Shoot length. B: Diameter of shoot.

2. 伸長成長, 菱径, 葉数, 葉径および腋芽誘導に及ぼ すジベレリンの影響

タラノキの伸長成長は, ジベレリン $10 \sim 200 \mathrm{mg} / 1$ 処理区 で伸長する傾向がみられたが（Fig. 2A），茎径については， ジベレリン散布区と無散布区の間に有意な差はみられなかっ た（Fig. 2B）。ジベレリン $500 \mathrm{mg} / 1$ 散布区は，無散布区に比 べて伸長成長が大きく抑制された。葉数は，ジベレリン 50 200 mg/1 散布区が無散布に比べ多かった（Table 2). 葉 径については，ジベレリン散布区が無散布に比べ小さかっ た。腋芽は，ジベレリン $200 \mathrm{mg} / 1$ 散布区でのみ誘導された (Fig. 3).

Table 1. Effects of ethephon spray concentration on all plants in $1 \mathrm{~m}^{2}$ on leaf numbers, leaf diameters and lateral formation in A. elata

\begin{tabular}{rccc}
\hline $\begin{array}{c}\text { Ethephon } \\
(\mathrm{mg} / \mathrm{l})\end{array}$ & $\begin{array}{c}\text { Leaf } \\
\text { numbers }\end{array}$ & $\begin{array}{c}\text { Width of } \\
\text { leaf } \\
(\mathrm{cm})\end{array}$ & $\begin{array}{c}\text { Length of } \\
\text { lateral bud } \\
(\mathrm{cm})\end{array}$ \\
\hline 0 & $6.4 \mathrm{~b}^{a)}$ & $5.3 \mathrm{~b}$ & 0 \\
50 & $6.8 \mathrm{~b}$ & $5.1 \mathrm{~b}$ & 0 \\
200 & $6.6 \mathrm{a}$ & $5.0 \mathrm{~b}$ & 0 \\
500 & $3.4 \mathrm{a}$ & $4.1 \mathrm{a}$ & 0 \\
1,000 & $-{ }^{b}$ & - & 0 \\
\hline
\end{tabular}

${ }^{a)}$ Means are separated within a column by Duncan's multiple range test at the $5 \%$ level. ${ }^{b)}$ No data on leaf following because of plant wilting. 

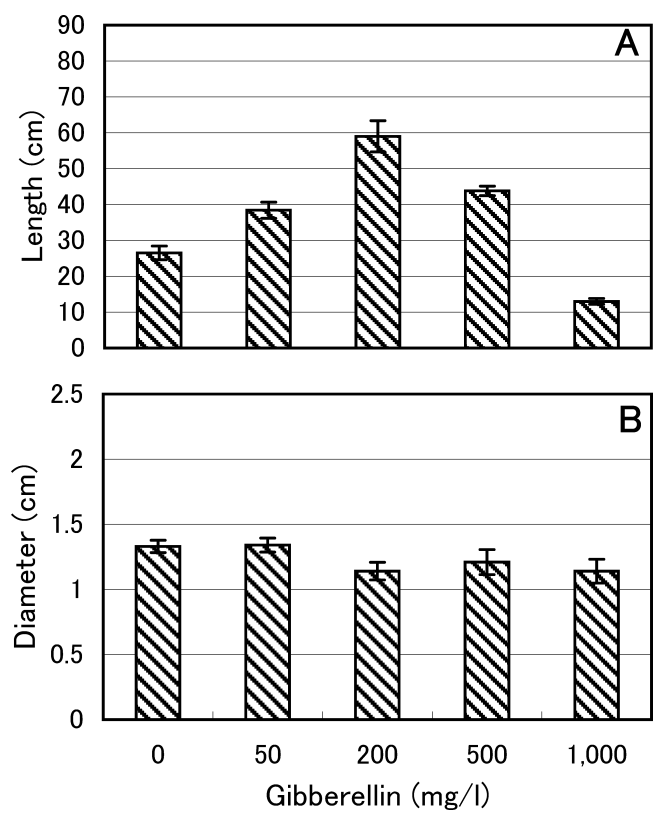

Fig. 2. Effects of gibberellin spray on all plants in the $1 \mathrm{~m}^{2}$ field on shoot elongation and diameters of stem leaves in A. elata. A: Shoot length. B: Diameter of shoot.

\section{3. 吸枝の生育に及ぼすエテフォンおよびジベレリンの影 響}

吸枝の発生は，ジベレリン処理区が最も多かった（Fig. 4A，Fig. 5). 無処理での吸枝数が $1 \mathrm{~m}^{2}$ あたり 2.5 本，エテ フォン処理区で 2.7 本であったのに対し，ジベレリン処理 区で 5.8 本と増加した。吸枝の草丈は無処理区が $15.9 \mathrm{~cm}$, エテフォン処理区が $26.4 \mathrm{~cm}$ であったのに対し，ジベレリン 処理区が $85.1 \mathrm{~cm}$ で最も伸長した（Fig. 4B）.

$$
\text { 考察 }
$$

タラノキにエテフォンを散布したところ，伸長成長が抑 制され，茎径が発達した。タラノキで主に食用とされるの

Table 2. Effects of gibberellin spray concentration on all plants in $1 \mathrm{~m}^{2}$ on leaf numbers, leaf diameters and lateral formation in A. elata.

\begin{tabular}{cccc}
\hline $\begin{array}{c}\text { Gibberellin } \\
(\mathrm{mg} / \mathrm{l})\end{array}$ & $\begin{array}{c}\text { Leaf } \\
\text { numbers }\end{array}$ & $\begin{array}{c}\text { Length of lateral } \\
\text { bud }(\mathrm{cm})\end{array}$ & $\begin{array}{c}\text { Width of } \\
\text { leaf }(\mathrm{cm})\end{array}$ \\
\hline 0 & $6.4 \mathrm{~b}^{a)}$ & 0 & $5.4 \mathrm{~b}$ \\
10 & $7.9 \mathrm{c}$ & 0 & $5.1 \mathrm{~b}$ \\
50 & $8.5 \mathrm{c}$ & 0 & $4.8 \mathrm{a}$ \\
200 & $9.2 \mathrm{c}$ & 3.4 & $4.1 \mathrm{a}$ \\
500 & $3.3 \mathrm{a}$ & 0 & $\left.-{ }^{b}\right)$ \\
\hline
\end{tabular}

${ }^{a)}$ Means are separated within a column by Duncan's multiple range test at the $5 \%$ level. ${ }^{b)}$ No data on leaf following because of plant wilting.

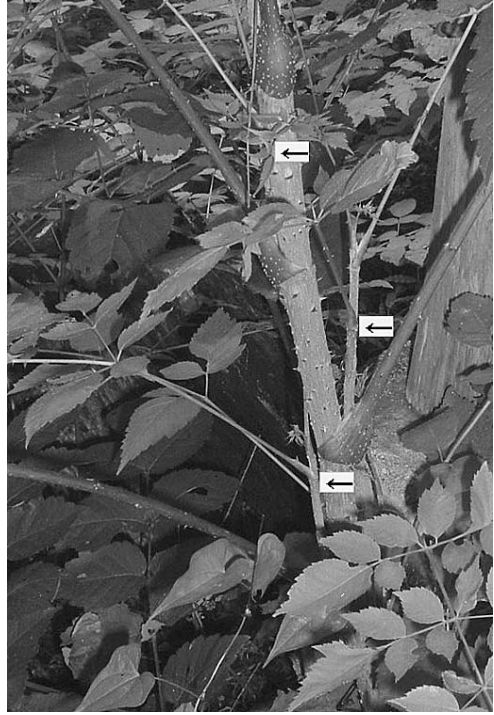

Fig. 3. Lateral bud formations with $200 \mathrm{mg} / \mathrm{l}$ gibberellin spray in A. elata. $\leftarrow$, Lateral bud.

は, 芽である ${ }^{1)}$. タラノキの芽は株の頂部に形成されるた め, 樹高が高いと収檴に多くの労力が必要である. そのた め, タラノキにエテフォンを散布することは, 収穫作業の 省力化につながる。 また, 茎の肥大促進による良質で大き な芽の収穫が期待できる.

タラノキにジベレリンを散布したところ, 腋芽が発達し た. 分枝が少なく 1 本の木からわずかな数しか芽が収檴で きない夕ラノキに扔いて, 腋芽の生育は分枝を促すため, 増収が期待できる。また，タラノキにジベレリンを散布し
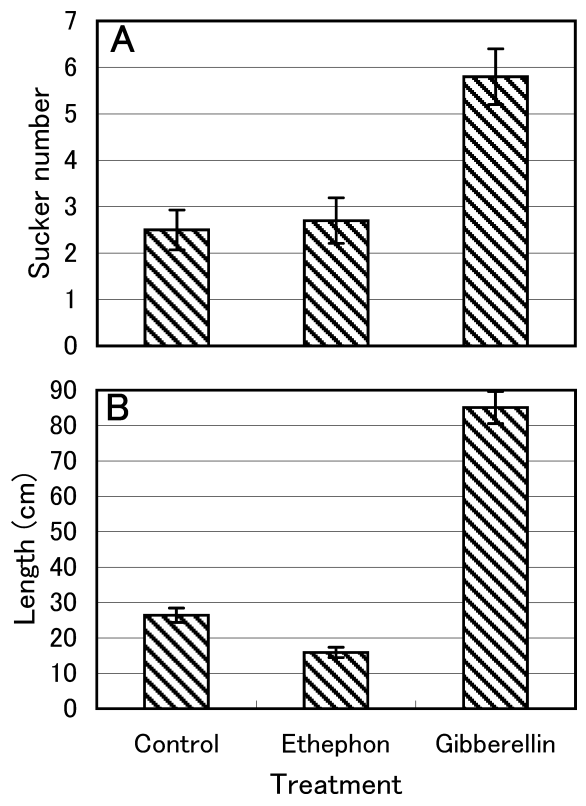

Fig. 4. Effects of ethephon and gibberellin applications on all plants in the $1 \mathrm{~m}^{2}$ field on sucker formation and sucker growth in $A$. elata. A: Sucker number. B: Sucker length. 


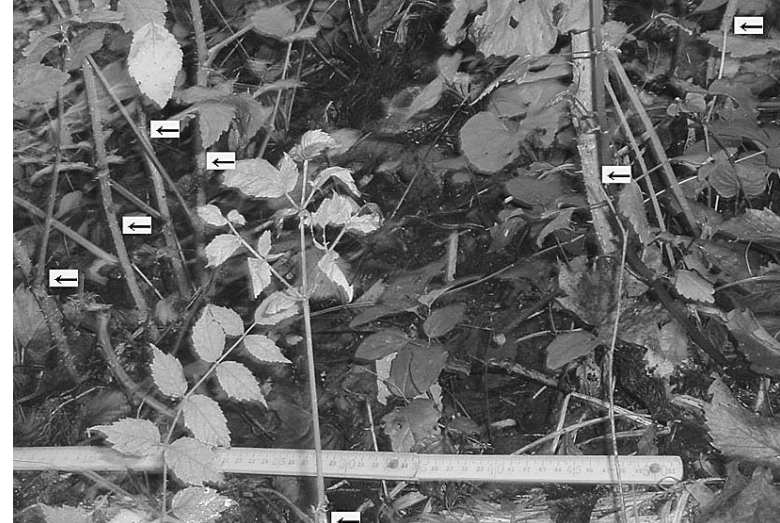

Fig. 5. Sucker formations with $200 \mathrm{mg} / 1$ gibberellin spray in $A$. elata. $\leftarrow$, Sucker.

たところ，吸枝が増加した。 タラノキの苗生産法として， 組織培養法や種子繁殖法があるが1,8)，組織培養による植物 の種苗生産は，馴化や定植等の手作業が必要である ${ }^{9)}$ 。一 方，吸枝による増殖はそれらの作業が不要なため，省力化 した増殖法として有用である。

一般に植物にエテフォン処理すると，エチレンが発生し 植物の伸長成長を抑制すると考えられているが，発生した エチレンの効果により内生オーキシン活性が高くなること で栄養成長が促進されると考えられている場合がある ${ }^{10-13)}$. 一般にオーキシン生成の高い組織ではエチレン生成活性と 内生オーキシン活性が供に高く，エチレン生成はオーキシ ンによって誘導されその濃度に依存する ${ }^{14)}$ 。また多くの双 子葉植物の黄化芽生えにエチレン処理をすると伸長成長が 阻害される ${ }^{15)}$. 同様にエテフォンの $1000 \sim 2000 \mathrm{mg} / \mathrm{l}$ をキク に処理すると処理植物の伸長成長は抑制される ${ }^{16,17)}$ 。この ことは，エセフォン処理により内生オーキシンレベルが高 くなりすぎ，その結果伸長成長が抑制されたためと思われ る．また，キクにおいてエチレンやエテフォンを一定の濃 度で処理すると，腋芽の生育が促進され，節間が短くなり， 葉が小さくなる2,10,17)。また，夏秋ギクではエテフォンを 100 300 mg/l で散布処理すると, 葉節数が大きく増加して 伸長成長が促進される2,13,18) が，抑制される品種もある18). そのため, 100 300 mg/1 のエテフォン処理による植物の伸 長成長への影響は，節間数の増加効果が節間伸長の抑制効 果を上回る植物では促進的に作用するが，節間数の増加効 果が少ないか全くない植物には抑制的に作用すると思われ る。また，夏秋ギクにジベレリンを散布すると，伸長成長 が促進される6,18)。しかし，タラノキにエテフォンを散布処 理した場合はキクの結果とは異なり，伸長成長が抑制され， 腋芽の発生はみられなかった。一方，ジベレリン処理は， 伸長成長が促進され, 腋芽が発生し, 葉が小さくなった。 タラノキでは，地上部へのジベレリン処理により吸枝の発 生数が著しく增加したが，タラノキの分枝や葉の縮小が,
エテフォンでなくジベレリンで誘導される機構については 不明で，今後詳細な検討が必要である。

以上より, タラノキはエテフォン散布により茎が肥大化 し，ジベレリン散布により伸長成長と吸枝による栄養繁殖 が促進された。

\section{要約}

タラノキの生育を調節する目的で，エテフォンとジベレ リンの生育に及ぼす影響を検討した。伸長成長と節間伸長 は，エテフォン $50 \sim 200 \mathrm{mg} / \mathrm{l}$ 処理区で対照無散布区より抑 制された。茎径は，エテフォン 50 200 mg/1 処理で増加し， 茥の肥大化が観察された。伸長成長之吸枝の発生は, ジベ レリン $50 \mathrm{mg} / 1$ 処理で促進された. ジベレリン $200 \mathrm{mg} / 1$ 処理 区では，腋芽が誘導された。

以上より，タラノキはエテフォン処理により茎が肥大化 し，ジベレリン処理により伸長成長と栄養繁殖が促進され た.

\section{引用 文 献}

1) 山口 聰, 村上ゆき枝, 上道秀一郎：愛媛大農演習林報 38, 37-44 (2000)

2) 杉浦広幸，藤田政良：園学研 2, 193-198 (2003a)

3）杉浦広幸，藤田政良：熱農業 47, 109-116 (2003b).

4) 山田常雄, 前川文夫, 江上不二夫，八杉竜一，小関治男, 古谷雅樹, 日高敏隆：生物学辞典第 3 版, 岩波書店, pp. $535-536,1986$

5) 勝見允行：生命科学シリーズ 植物のホルモン, 裳華房, pp. 50-82, 1991.

6) 野中瑞生：農業技術体系 花卉編, 6. キク（クリサンセ マム), 坂本 尚編, 農山漁村文化協会, pp. 187-192, 1996.

7) 由井秀樹：農業技術体系 花卉編，6。キク（クリサンセ マ厶), 坂本 尚編, 農山漁村文化協会, pp. 359-363, 1996.

8) N. Yoshizawa, H. Shimizu, Y. Wakita, S. Yokota and T. Idei: Bull. Utsunomiya Univ. For. 30, 19-26 (1994).

9) H. Sugiura, S. G. Agong, A. Enami, H. Kaneko and T. Honma: African Crop Sci. J. 8, 117-127 (2000).

10) S. B. O. Tjia, N. M. Rogers and E. D. Hartley: J. Am. Sci. Hort. Sci. 94, 35-39 (1969)

11) W. P. Hackett: Hort. Rev. 7, 109-155 (1985).

12) H. L. Warner and A. C. Leopold: Plant Physiol. 44, 156-158 (1969).

13) 中山昌明, 由井秀樹：信州大農学部紀要 25, 1-13 (1988)

14) 福田裕穂, 町田泰則, 神谷勇治, 服部束穂: 植物ホルモ ンのシグナル伝達，須摩春樹編，秀潤社，pp. 138-149, 1985.

15) M. A. Kher, M. Yokoi and K. Kosugi: J. Jpn. Soc. Hort. Sci. 43, 91-96 (1974)

16）小西国義, 梶原真二, 景山詳弘：園学雑 54, 87-93 (1985).

17) C. J. Stanley and K. E. Chockshull: J. Hort. Sci. 64, 341-350 (1989).

18）谷川孝弘：農業および園芸 75, 270-280 (2000) 